\title{
HUBUNGAN ANTARA FAKTOR KUALITAS PRODUK, KUALITAS PELAYANAN, LOKASI DAN LINGKUNGAN DENGAN KEPUTUSAN PEMBELIAN SUSU SEGAR
}

\author{
(The Relationship Between Factors Of Product Quality, Services Quality, Location, And \\ Environment With Purchasing Decision Of Fresh Milks)
}

\author{
Robertus Eri Triawan', Hendrik Johannes Nadapdap², \\ Bayu Nuswantara ${ }^{3}$ \\ Fakultas Pertanian dan Bisnis, \\ Universitas Kristen Satya Wacana Salatiga \\ Email : oberteri93@gmail.com¹, hendrik.nadapdap@uksw.edu ${ }^{2}$, bnuswan@gmail.com
}

Article Submitted : 23-04-2019

Article Accepted : 10-06-2019

\begin{abstract}
The fresh milk is an animal food that has high nutrition and provides great benefits for humans. At present the development of fresh milk sales in Salatiga is experiencing rapid development in line with the growing culinary place. The decision to buy fresh milk is an interaction of internal and external factors within the scope of marketing. The purpose of this study was to determine the relationship between product quality, service quality, location and environment with the decision to remove fresh milk at the Salatiga Stasiun Susu cafe. This type of research is quantitative descriptive using the survey method. Data collection is done by observation and interviews using questionnaires. The research location was set deliberately at the Salatiga Stasiun Susu cafe. Sampling uses a nonprobability sampling of visitors 16 to 25 years old who consume and buy fresh milk at the Susu Stasiun cafe. The sampling technique was done by accidental sampling with a total of 50 respondents. Data analysis with rank spearman. The results showed that there was a positive and significant relationship between product quality, service quality, location and environment to the decision to purchase fresh milk.
\end{abstract}

Keywords: fresh milks, marketing, purchasing decision

\section{PENDAHULUAN}

Susu segar merupakan bahan makanan yang bergizi tinggi karena di dalam susu segar mengandung berbagai zat makanan yang lengkap dan seimbang seperti protein, lemak, karbohidrat, mineral, dan vitamin yang sangat dibutuhkan oleh tubuh manusia. Kebutuhan gizi masyarakat dari susu dapat dikategorikan dari umur, yaitu usia 0-12 bulan belum dianjurkan untuk mengkonsumsi susi sapi melainkan harus mengkonsumsi susu ASI, usia
1-10 tahun dianjurkan untuk mengkonsumsi susu $150 \mathrm{ml}$ per hari, usia 11-19 tahun dianjukan untuk mengkonsumsi susu $250 \mathrm{mil}$ per hari dan usia 20 tahun keatas dianjurkan untuk mengkonsumsi $200 \mathrm{ml}$ per hari. Usia yang paling dianjurkan untuk mengkonsumsi susu paling banyak adalah usia 11-19 tahun setelah itu berkurang sedikit dalam pola konsumsi. Susu segar merupakan salah satu satu produk minuman yang berasal dari susu sapi. Susu segar biasanya memiliki warna putih dan rasa plain yang cenderung gurih, namun 
kini sudah diolah dengan rasa tertentu kemudian dikemas dalam kemasan yang menarik (Kementrian Pertanian, 2015).

Olahan susu segar merupakan salah satu cara supaya lebih diterima oleh lidah orangorang yang tidak suka dengan rasa plain dari susu segar tersebut. Produk susu segar yang sudah diolah merupakan salah satu minuman yang telah banyak diminati konsumen sehingga kualitas produk harus dipertahankan, dimulai sejak penentuan standar kualitas serta proses pengadaan bahan baku yang akan digunakan, proses produksi dilaksanakan hingga proses penjualan produk kepada konsumen (Safitri,I., D, Salman, 2018).

Tempat- tempat yang dituju harus memiliki strategi dalam penjualan produknya karena penjualan sangat erat kaitannya dengan keputusan pembelian. Menurut (Schiffman \& Kanuk, 2007) keputusan adalah seleksi terhadap pilihan alternatif atau lebih. Pilihan alternatif harus tersedia bagi seseorang ketika mengambil sebuah keputusan. Keputusan pembelian merupakan sikap seseorang untuk membeli atau menggunakan suatu produk baik berupa barang ataupun jasa. Menurut (Aldi, 2012) keputusan pembelian yang diambil oleh pembelian sebenarnya merupakan kumpulan dari sejumlah keputusan yang terorganisir. Keputusan pembelian tidak hanya berpedoman pada harga yang murah saja, tetapi juga pada kualitas pelayanan, lokasi usaha, kualitas produk yang ditawarkan, serta lingkungan usaha dan lain sebagainya (Yuliani, 2010)

Kafe menjadi salah satu tempat kunjungan anak muda untuk berdiskusi dengan teman-teman dan sudah menjadi gaya hidup anak muda. Banyak kafe yang beredar saat ini terutama di Kota Salatiga menawarkan berbagai macam produk seperti kafe yang khusus menjual produk susu yang berbagai varian rasa. Stasion susu adalah salahsatu kafe di Salatiga yang khusus menjual produk susu dan ramai dikunjungi. Sejak berdiri, statsiun susu selalu menjaga kualitasnya yang mana susu yang digunakan adalah susu sapi segar dengan TS (Total Solid) tinggi yang diperoleh dari sapi yang beranak 3 sehingga susu yang dihasilakan masih sangat bagus. Berdasarkan latar belakang diatas peneliti menjadi tertarik untuk melakukan penelitian di cafe Stasiun Susu Salatiga karena belum ada penelitian yang meneliti tentang hubungan faktor kualitas produk, kualitas pelayanan, lokasi dan lingkungan dengan keputusan pembelian susu segar. Penelitian ini bertujuan untuk mengetahui hubungan antara faktor kualitas produk, kualitas pelayanan, lokasi dan lingkungan dengan keputusan pembelian susu segar.

\section{METODE PENELITIAN}

Kegiatan penelitian telah dilaksanakan pada bulan Januari-Februari 2019 selama kurang lebih 30 hari. Tempat penelitian berlokasi di Cafe Stasiun Susu, Kota Salatiga, Jawa Tengah. Pemilihan lokasi ini dilakukan secara sengaja (purposive) dengan pertimbangan di tempat tersebut merupakan tempat penjualan susu pertama di Salatiga yang memiliki menu susu yang sangat variatif dan inovatif dari segi rasa serta mengombinasikan susu sapi segar dengan aneka rasa buah, coklat dan karamel.

Penelitian ini menggunakan jenis penelitian deskriptif kuantitatif. Pengambilan sampel dalam penelitian ini menggunakan accidental sampling. Accidental sampling adalah teknik penentuan sampel berdasarkan kebetulan, yaitu siapa saja yang secara kebetulan dengan peneliti dapat digunakan sebagai sampel, bila dipandang orang yang kebetulan ditemui itu cocok sebgai sumber data (Sugiyono, 2013). Sampel yang digunakan dalam peneilitian ini berjumlah 50 orang yang merupakan konsumen di Cafe Stasiun Susu. Jenis data yang digunakan dalam penelitian ini adalah data primer yang diperoleh dengan 
menggunakan metode survey dengan cara wawancara melalui panduan kuisioner.

Alat analisis menggunakan uji korelasi Rank Spearman. Koefisien korelasi Rank Spearman digunakan untuk mengetahui tingkat derajat keeratan dua variabel yang memiliki skala pengukuran minimal, ordinal (Siagian, 2009). Untuk menghitung koefisien korelasi maka data diberikan peringkat dari 1 sampai $n$ bedasarkan urutan kepentingan dan lain sebagainya. (Murray R, 2006). Pengolahan data dilakukan dengan menggunakan SPSS versi 16.0 for windows. Uji t digunakan untuk melakukan pengujian terhadap koefisien regresi secara parsial, pengujian ini dilakukan untuk mengetahui signifikansi peranan secara parsial antara variabel independen terdahap variabel dependen dengan ansumsi bahwa variabel independen lainnya dianggap konstan (Sugiyono, 2013).

\section{HASIL DAN PEMBAHASAN}

\section{Distribusi Karakteristik Responden}

Distribusi karakteristik responden dalam penelitian ini dapat dilihat dari jenis kelamin, pendidikan, usia konsumen yang menjadi responden penelitian mengenai hubungan faktor kualitas produk, kualitas pelayanan, lokasi dan lingkungan dengan keputusan pembelian susu segar di cafe Stasiun Susu Salatiga.

Responden dalam penelitian ini berjumah 50 orang dan akan dijadikan persentase yaitu 100 persen.

\section{Karakteristik Responden Berdasarkan Jenis Kelamin \\ Berdasarkan jenis kelamin responden di cafe Staiun Susu, terlihat pada tabel 1 berikut ini :}

Tabel 1. Karakteristik Responden Berdasarkan Jenis Kelamin

\begin{tabular}{lcc}
\hline Jenis Kelamin & Jumlah (Orang) & Persentase (\%) \\
\hline Laki-laki & 26 & 52 \\
Perempuan & 24 & 48 \\
\hline \multicolumn{1}{c}{ Jumlah } & 50 & 100 \\
\hline
\end{tabular}

Sumber : data primer yang diolah,2019

Pada Tabel 1 di atas, menunjukkan bahwa jumlah responden yang paling banyak adalah jenis kelamin laki-laki sebanyak 26 orang dengan persentase $52 \%$.

\section{Karakteristik Responden Berdasarkan Pendidikan}

Berdasarkan pendidikan responden, kriteria pendidikan formal yang digunakan adalah sekolah dasar hingga sarjana seperti terlihat pada tabel 2 berikut ini:

Tabel 2. Karakteristik Responden Berdasarkan Pendidikan :

\begin{tabular}{lcc}
\hline \multicolumn{1}{c}{ Pendidikan } & Jumlah (Orang) & Persentase (\%) \\
\hline SD & 0 & 0 \\
SMP & 0 & 0 \\
SMA/SMK & 15 & 30 \\
D3/Sarjana & 35 & 70 \\
\hline \multicolumn{1}{c}{ Jumlah } & 50 & 100 \\
\hline
\end{tabular}

Sumber : data primer yang diolah,2019 
Pada Tabel 2, di atas menunjukkan bahwa jumlah reponden paling banyak adalah responden yang memiliki pendidikan D3/Sarjana dengan persentase 70\%, menunjukan bahwa konsumen yang datang ke Stasiun Susu segar didominasi oleh mahasiswa atau masyarakat umum yang pendidikannya hingga sarjana atau diploma karena. Mahasiswa sering mengunjungi Stasiun Susu karena untuk kumpul dengan teman-temannya. Salatiga memiliki banyak jumlah mahasiswa karena karena kota salatiga memiliki beberapa perguruan tinggi yang mahasiswa berasal dari dalam maupun luar kota Salatiga.

\section{Karakteristik Responden Berdasarkan Usia}

Berdasarkan usia responden di cafe Stasiun Susu yang memiliki beragam usia mulai dari usia muda sampai dengan usia cukup tua seperti terlihat pada tabel 3

Tabel 3. Karakteristik Responden Berdasarkan Usia

\begin{tabular}{lcc}
\hline Usia & Jumlah (orang) & Persentase (\%) \\
\hline $17-22$ & 31 & 62 \\
$23-28$ & 9 & 18 \\
$29-34$ & 5 & 10 \\
$35-40$ & 1 & 2 \\
$41-46$ & 2 & 4 \\
$47-52$ & 2 & 4 \\
\hline Jumlah & 50 & 100 \\
\hline
\end{tabular}

Sumber : data primer yang diolah,2019

Pada Tabel 3 di atas, menunjukkan bahwa jumlah responden berusia 17-22 tahun sebanyak $62 \%$ kemudian responden dengan usia 23-28 tahun sebanyak 18\%, responden dengan usia 29-34 tahun sebanyak 10\%, responden dengan usia 35-40 tahun sebanyak $2 \%$, responden dengan usia 41-46 tahun sebanyak 4\%, responden dengan usia 47-52 tahun sebanyak 4\%, Pada tabel diatas umur yang paling banyak melakukan pembelian susu segar ialah pada umur 17-22 tahun dengan persentase sebesar $62 \%$. Hal tersebut berkaitan dengan tabel 2 yang menunjukan jumlah mahasiswa yang berada di kota Salatiga rata-rata berumur 17-22 tahun.

\section{Hubungan Faktor Kualitas Produk, Kualitas Pelayanan, Lokasi dan Lingkungan dengan Keputusan Pembelian di Cafe Stasiun Susu}

Hubungan antara faktor kualitas produk $\left(\mathrm{X}_{1}\right)$, kualitas pelayanan $\left(\mathrm{X}_{2}\right)$, lokasi $\left(\mathrm{X}_{3}\right)$ dan lingkungan $\left(\mathrm{X}_{4}\right)$ dengan keputusan pembelian (Y) di cafe Stasiun Susu dapat diketahui dengan menggunakan uji Rank Spearman ( $\mathrm{r}_{\mathrm{S}}$ ). 
Tabel 4. Hubungan antara Faktor Kualitas Produk $\left(\mathrm{X}_{1}\right)$, Kualitas Pelayanan $\left(\mathrm{X}_{2}\right)$, Lokasi $\left(\mathrm{X}_{3}\right)$ dan Lingkungan $\left(\mathrm{X}_{4}\right)$ dengan Keputusan Pembelian (Y) di cafe Stasiun Susu.

\begin{tabular}{lcccccl}
\hline \multicolumn{1}{c}{ Variabel } & $\left(\mathrm{r}_{\mathrm{s}}\right)$ & $\alpha(0,05)$ & $\mathrm{t}$ hitung & $\mathrm{t}$ tabel & $\begin{array}{c}\text { Hasil uji } \\
\text { Statistik }\end{array}$ & $\begin{array}{c}\text { Tingkat } \\
\text { keeratan } \\
\text { hubungan }\end{array}$ \\
\hline Kualitas Produk & $0.616^{* *}$ & 0.000 & 5.41 & 2.14 & Signifikan & Kuat \\
Kualitas Pelayanan & $0.614^{* *}$ & 0.000 & 5.34 & 2.14 & Signifikan & Kuat \\
Lokasi & $0.452^{* *}$ & 0.001 & 3.50 & 2.14 & Signifikan & Sedang \\
Lingkungan & $0.365^{* *}$ & 0.009 & 2.71 & 2.14 & Signifikan & Rendah \\
\hline
\end{tabular}

Sumber : data primer yang diolah,2019

Keterangan : $r_{s}=$ Koefisien Korelasi

** : Signifikan pada taraf $\alpha=0,01(1 \%)$

* : Signifikan pada taraf $\alpha=0,05(5 \%)$

Hubungan Antara Kualitas Produk $\left(X_{1}\right)$ dengan Keputusan Pembelian di cafe Stasiun Susu (Y)

Hasil dari tabel 4, dapat dilihat bahwa nilai koefisien korelasi antara kualitas produk dengan keputusan pembelian di Stasiun Susu sebesar 0,616 dengan tanda positif dan nilai signifikansinya 0,000 . Hal ini menunjukkan bahwa kualitas produk memiliki hubungan yang nyata serta tingkat hubungan yang kuat dengan keputusan pembelian di cafe Stasiun Susu, dimana koefisien kualitas produk berada pada interval 0,60-0,79 sesuai dengan interpretasi kuatnya hubungan korelasi menurut (Sugiyono, 2013).

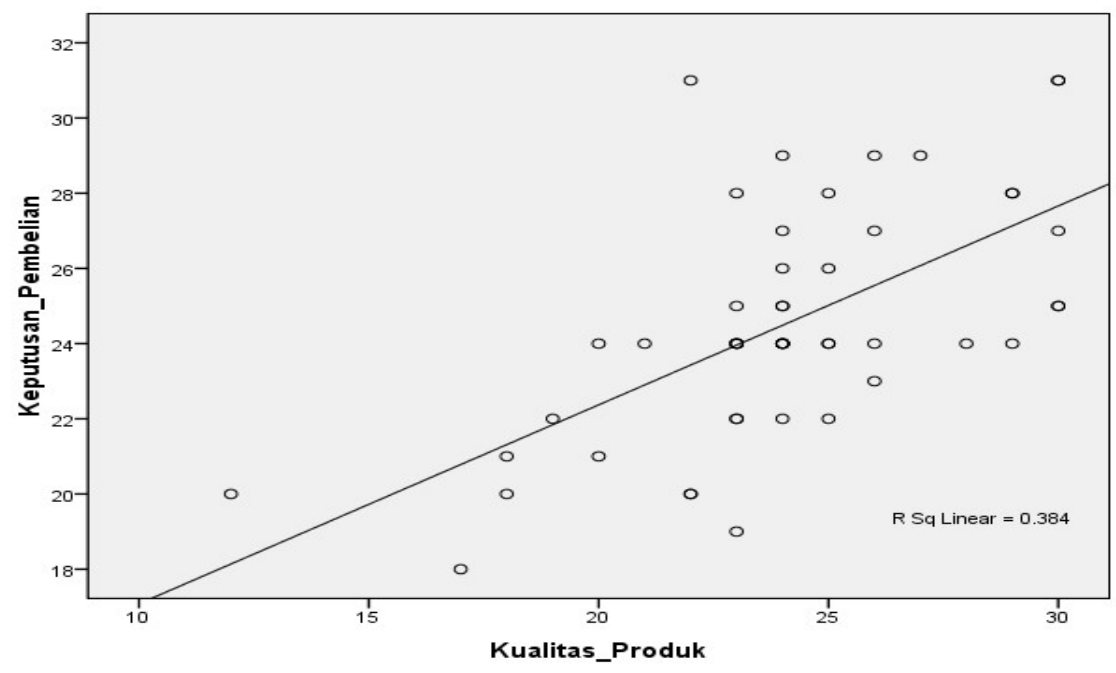

Gambar 1. Grafik Responden Kualitas Produk $\left(\mathrm{X}_{1}\right)$ dengan Keputusan Pembelian di cafe Stasiun Susu

Kualitas produk memiliki hubungan yang nyata memiliki arti bahwa semakin kualitas produk ditingkatkan maka semakin besar pula keputusan pembelian dan 
sebaliknya. Hasil penelitian ini juga sesuai dengan penelitian (Hartono, B et al, 2010) menyatakan meningkatnya kualitas produk susu maka akan meningkat pula keputusan pembelian konsumen. Responden juga tertarik akan warna dan bentuk pada saat susu segar disajikan serta mereka juga tertarik dengan kemasan susu segar yang sangat menarik.

Berdasarkan frekuensi jawaban responden diketahui kualitas produk yang diterima oleh responden termasuk ketegori kuat, responden melakukan pembelian susu segar karena memang memiliki cita rasa yang khas dan pada saat dikonsumsi susu masih segar dan tidak berbau amis dan basi. Responden juga tertarik pada banyaknya pilihan rasa yang disajikan serta mereka juga tertarik dengan bentuk kemasan susu segar yang sangat menarik. Kualitas produk yang diberikan oleh tempat penjualan susu segar di atas akan membuat responden cepat dalam memutuskan pembelian susu segar.

\section{Hubungan Antara Kualitas Pelayanan $\left(\mathbf{X}_{2}\right)$ dengan Keputusan Pembelian di cafe Stasiun Susu (Y)}

Hasil dari tabel 4, dapat dilihat bahwa nilai koefisien korelasi yang kuat antara kualitas pelayanan dengan keputusan pembelian di Stasiun Susu sebesar 0.614 dengan nilai signifikansinya 0,000 . Hubungan yang nyata antara kualitas pelayanan dengan keputusan pembelian susu memili arti bahwa kualitas pelayanan semakin ditingkatkan maka semakin besar pula keputusan pembelian dan sebaliknya. Hasil ini sesuai dan memperkuat penelitian sebelumnya khususnya penelitian dari (Apriyani,A., 2017) yaitu kualitas pelayanan yang terdiri dari bukti fisik, keandalan, daya tanggap, jaminan dan empati secara bersama-sama memiliki pengaruh yang signifikan terhadap kepuasan konsumen.

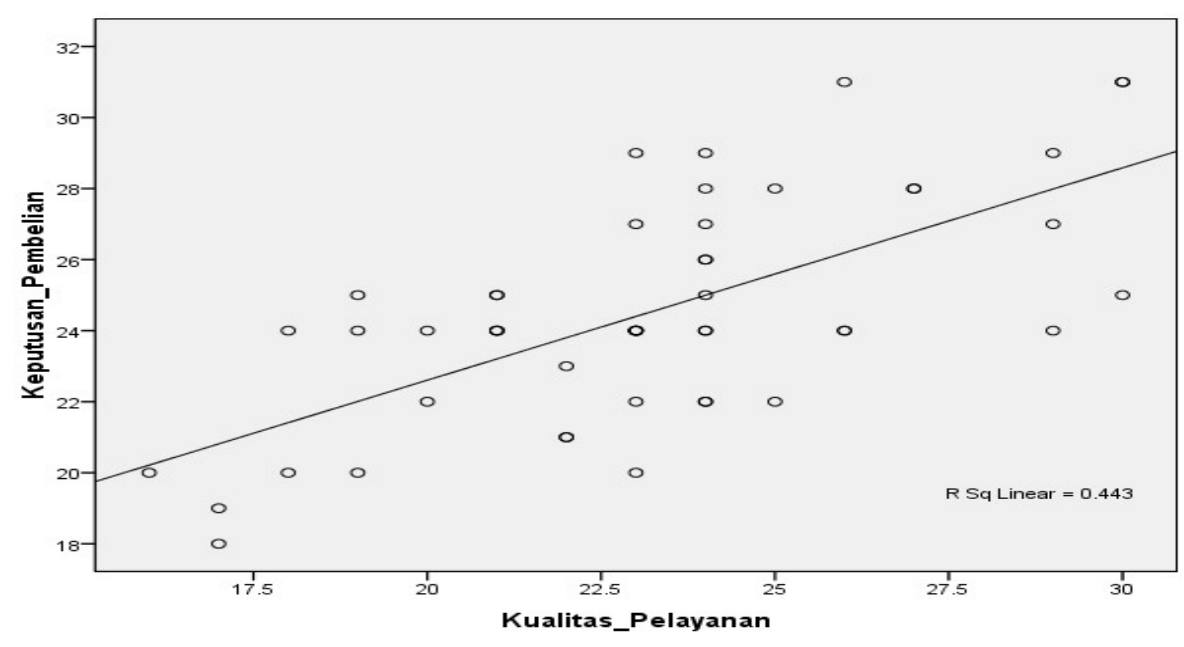

Gambar 2. Grafik Responden Kualitas Pelayanan $\left(\mathrm{X}_{2}\right)$ dengan Keputusan Pembelian di cafe Stasiun Susu

Berdasarkan frekuensi jawaban responden diketahui kualitas pelayanan yang diterima oleh responden termasuk ketegori kuat, responden melakukan pembelian susu segar karena memang pelayanan di cafe Stasiun Susu sangat ramah selain itu juga Sistem pemesanan yang cepat dan handal mengantar pesanandan responden terbantu 
karena pegawainya memberikan info tempat duduk yang masih kosong serta membantu mencatat pesanan. Pelayanan yang memuaskan di atas akan membuat responden cepat dalam memutuskan pembelian susu segar. Pelayanan yang diberikan oleh Kafe Stasion Susu juga menyapa hangat pengunjungnya dan bahkan tidak jarang pemilik kafe menghampiri pengunjung dan bercerita dengan pengunjung sehingga membangun kedekatan hubungan. Hal tersebut membuat pengunjung untuk melakukan kunjungan pembelian berulang.

\section{Hubungan Antara Lokasi ( $\left.\mathbf{X}_{3}\right)$ dengan Keputusan Pembelian di cafe Stasiun Susu (Y)}

Hasil dari tabel 4, dapat dilihat bahwa nilai koefisien korelasi yang sedan antara lokasi dengan keputusan pembelian di Stasiun Susu sebesar 0.452 dengan tanda positif dan signifikansinya 0,001 . Hal ini menunjukkan bahwa lokasi memiliki hubungan yang positif dan signifikan dengan keputusan pembelian di cafe Stasiun Susu. Hubungan lokasi dengan keputusan pembelian susu yang nyata memiliki arti bahwa semakin terjangkau lokasi penjualan semakin besar juga keputusan pembelian susu segar dan sebaliknya semakin jauh lokasi penjualan maka semakin berkurangnya jumlah pembelian. Hasil ini sesuai dan memperkuat penelitian sebelumnya yang mana strategi lokasi terbukti memiliki pengaruh terhadap keputusan pembelian konsumen. (Walukow, 2014).

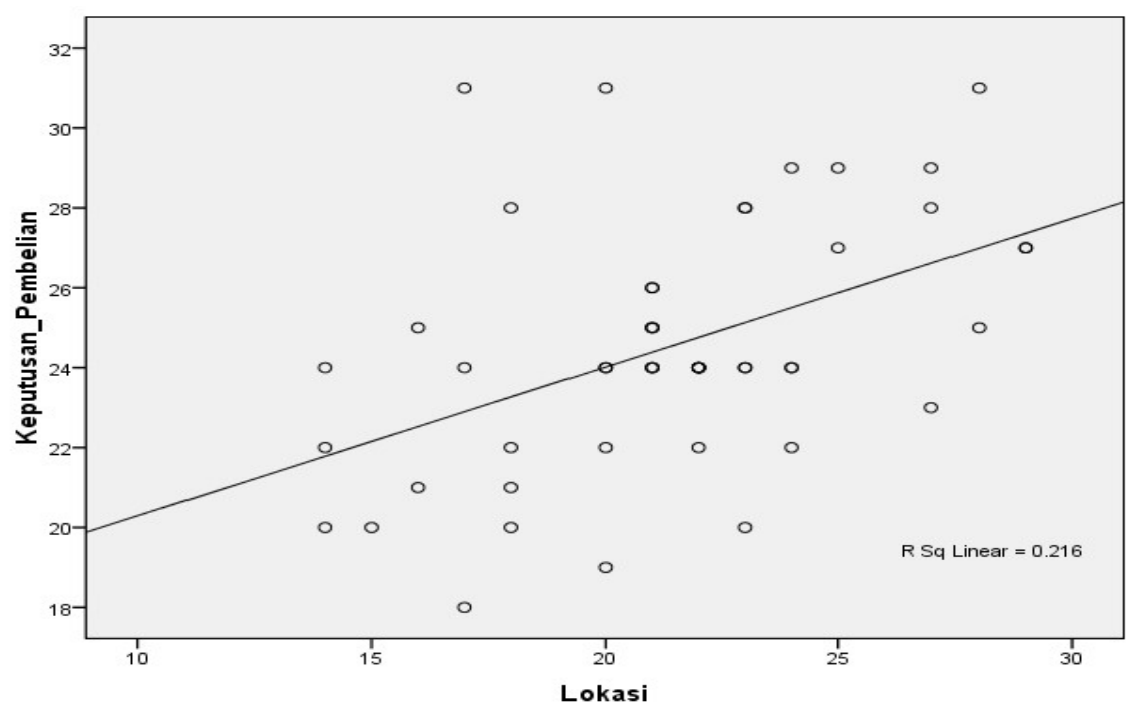

Gambar 3. Grafik responden Lokasi $\left(\mathrm{X}_{3}\right)$ dengan Keputusan Pembelian di cafe Stasiun Susu

\begin{abstract}
Berdasarkan frekuensi jawaban responden diketahui lokasi memiliki hubungan terhadap keputusan pembelian karena responden melakukan pembelian susu segar ketempat yang mudah terjangkau, tempat parkir yang luas, nyaman serta aman. Selain itu, responden juga memilih tempat penjualan yang dekat dengan rumah serta
\end{abstract}

dekat dengan jalan raya sehingga mempermudah akses bagi mereka yang tidak memiliki kendaraan maupun yang memiliki kendaraan karena kondisi jalan yang lebar. Disamping itu, letak lokasi Kafe Stasiun Susu yang sangat bersih dan penataan ruangan yang membuat konsumen nyaman untuk berdiskusi lama. 


\section{Hubungan Antara Lingkungan $\left(\mathrm{X}_{4}\right)$ dengan Keputusan Pembelian di cafe Stasiun Susu (Y)}

Hasil dari Tabel 4, dapat dilihat bahwa nilai koefisien korelasi rendah antara lingkungan dengan keputusan pembelian di Stasiun Susu sebesar 0.365 dengan tanda positif dan signifikan pada taraf kepercayaan 0,009. Hal ini menunjukkan bahwa lingkungan memiliki hubungan yang positif serta tingkat hubungan yang nyata dengan keputusan pembelian di cafe Stasiun Susu.
Hubungan yang nyata antara lingkungan dengan keputusan pembelian memiliki arti bahwa lingkungan keluarga dan lingkungan sosial mempengaruhi konsumen untuk membeli susu segar selain itu banyak dari konsumen merupakan orang dari Kota Salatiga sehingga lingkungan keluarga berpengaruh dengan keputusan pembelian. Hasil penelitian Ria, R dan Yuliawati (2018) mendukung penelitian ini bahwa lingkungan sosial berkorelasi signifikan terhadap keputusan pembelian suatu produk susu.

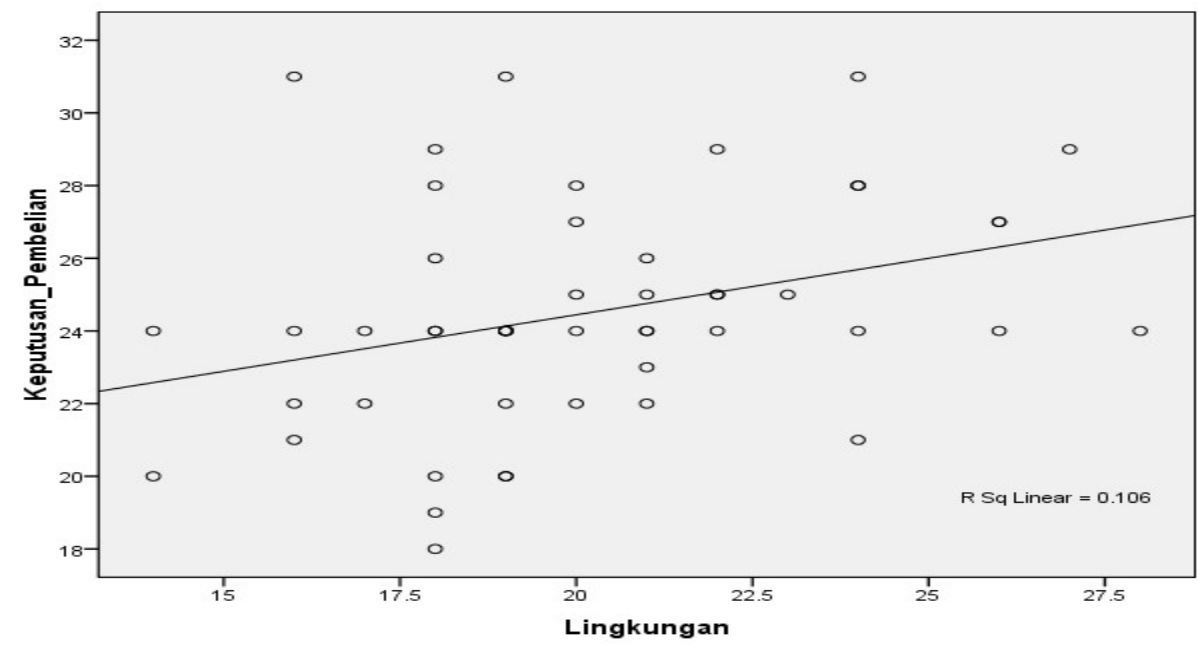

Gambar 4. Grafik Responden Lingkungan $\left(\mathrm{X}_{4}\right)$ dengan Keputusan Pembelian di cafe Stasiun Susu

Berdasarkan frekuensi jawaban responden diketahui bahwa lingkungan memiliki hubungan rendah terhadap keputusan pembelian, keluarga bukan faktor utama responden membeli susu, selain itu lingkungan di sekitar tempat tinggal responden tidak banyak yang menjual susu segar, serta lingkungan di sekitar Cafe Stasiun Susu yang sepi sehingga membuat konsumen biasa bersantai.

\section{KESIMPULAN DAN SARAN Kesimpulan}

Berdasarkan hasil analisis dan pembahasan penelitian tentang hubungan faktor kualitas produk, kualitas pelayanan, lokasi, dan lingkungan dengan keputusan pembelian di cafe Stasiun Susu, Salatiga dapat dilihat nilai koefisien korelasi $\left(\mathrm{r}_{\mathrm{s}}\right)$ dengan tingkat keeratan hubungan sebagai berikut:

1. Kualitas produk $\left(\mathrm{X}_{1}\right)$ memiliki hubungan yang signifikan dan positif, serta memiliki tingkat hubungan yang kuat dengan keputusan pembelian susu segar (Y).

2. Kualitas palayanan $\left(\mathrm{X}_{2}\right)$ memiliki hubungan yang signifikan dan positif, serta tingkat hubungan yang kuat keputusan pembelian susu segar (Y).

3. Lokasi $\left(\mathrm{X}_{3}\right)$ memiliki hubungan yang 
signifikan dan positif, serta memiliki tingkat hubungan yang sedang dengan keputusan pembelian (Y).

4. Lingkungan $\left(\mathrm{X}_{4}\right)$ memiliki hubungan yang signifikan dan positif, serta memiliki tingkat hubungan yang rendah dengan keputusan pembelian (Y).

\section{Saran}

Berdasarkan pembahasan dan kesimpulan diatas, maka dapat di rekomendasikan saran penelitian sebagai berikut :

1. Pihak Stasiun Susu diharapkan lebih mempertahankan dan meningkatkan kualitas produk susu dan kualitas pelayanan karena kedua variabel tersebut memiliki hubungan yang kuat terhadap keputusan pembelian susu agar menjadi strategi pemilik susu untuk meningkatkan jumlah kunjungan konsumen.

2. Bagi peneliti selanjutnya, diharapkan dapat melakukan penelitian ini dengan meneliti faktor lain yang dapat mempengaruhi keputusan pembelian, misalnya faktor budaya dan variabel harga.

\section{DAFTAR PUSTAKA}

Aldi, A. (2012). Pengaruh Citra Merek dan Kualitas Produk terhadap Keputusan Pembelian Konsumen Motor Satria FU di Klaten (UNIVERSITAS NEGERI YOGYAKARTA). Retrieved from Thesis (S1)

Apriyani,A., D. dan S. (2017). Pengaruh Kualitas Pelayanan Terhadap Kepuasan Konsumen (Survei pada Konsumen The Little A Coffee Shop Sidoarjo). Administrasi Bisnis, 51, 1-7.

Azwar, S. (2013). Metode Penelitian. Retrieved from https://mepsychology.wordpress.com/201 4/12/01/validitas-dan-reliabilitas/

Ghozali, I. (2012). Aplikasi Analisis Multivariat dengan Program IBM SPSS 20 (Edisi keenam). Semarang: Universitas Diponegoro.

Hartono, B et al. (2010). Analisis Faktor-

Faktor Yang Mempengaruhi Konsumen

Dalam Membeli Produk Susu

Pasteurisasi Kabupaten Kudus. Buletin

Peternakan, 34, 123-130.

Kementrian Pertanian. (2015). Kebutuhan Gizi Masyarakat Indonesia. Retrievedfrom http//sipd.kemendagri.go.id/dokumen/upl oads/rtrw_241_2016.pdf website: http//sipd.kemendagri.go.id/dokumen/upl oads/rtrw_241_2016.pdf.

Murray R. (2006). Probebilitas dan Statistik (L. Simarmata, Ed.). Jakarta: Erlangga.

Ria, R dan Yuliawati. (2018). Hubungan harga, lokasi, kualitas produk, kualitaspelayanan dan lingkungan terhadapkeputusan pembelian susu segar di kecamatan sidorejo, salatiga, jawa tengah. Sosial Ekonomi Pertanian, 14, $195-209$.

Safitri,I., D, Salman, R. (2018). Strategi Pengembangan Usaha Kuliner: Studi Kasus Warung Lemang di Jeneponto, Sulawesi Selatan. Jurnal Sosial Ekonomi Pertanian, 14, 183-194.

Schiffman, L. G., \& Kanuk, L. L. (2007). Consumer behavior, 7th.

Siagian, S. P. (2009). Kiat Meningkatkan Produktivitas Kerja . Jakarta. PT Rineka Cipta. J. Electron. Commer. Res.

Sugiyono. (2013). Metode Penelitian 
Kuantitatif dan R\&D. In Jurnal Ilmiah Mahasiswa Pendidikan Kimia.

Syofian Siregar. (2013). Statistika parametrik untuk penelitian kuantitatif. Bumi Aksara.

Walukow. (2014). Pengaruh Kualitas Produk, Harga, Promosi dan Lokasi Terhadap Keputusan Pembelian Konsumen di
Bentenan center Sonder Minahasa. EMBA, 12, 1686-1814.

Yuliani. (2010). Analisis Pengaruh Lokasi, Promosi dan Kualitas Layanan Terhadap Keputusan Membeli. Universitas Diponegoro. Semarang. 